\title{
STATISTICAL ANALYSIS OF THE EFFECT OF DRUG ABUSE ON ACADEMIC PERFORMANCE IN WUKARI
}

\author{
Okorie Charity Ebelechukwu, Omale Caroline, Ochigbo Josephine E. Ben Johnson Obakpo \\ Department of Mathematics and Statistics, \\ Federal University Wukari, Taraba State, Nigeria
}

\begin{abstract}
This research work is concerned with the effects of drug abuse on academic performance. The reason for this research is because it was observed that whenever students begin to involve themselves in drug abuse, they start to perform poorly in their academics. Data were collected through distribution of questionnaires in Wukari, Taraba State. The number of questionnaires given out was 215 and the number realized was 182 . Chisquare was used for the analysis and it was observed that drug abuse has effect on students' academic performance.
\end{abstract}

Keywords: Drug abuse, Academics, Analysis, Performance, Effect

\section{INTRODUCTION}

Drug is any product other than food or water that affects physical, mental and emotional functioning (Lewinsohn,2007). It can enter the body through chewing, inhaling, smoking, drinking, rubbing on the skin or injection. The World Health Organization also defined drug abuse as a "state" of periodic or chronic intoxication, detrimental to the individual and to the society, produced by the repeated consumption of a drug (natural or synthetic) (WHO, 2006). Drug abuse is the excessive, maladaptive or addictive use of drugs for non-medical purpose (Manbe,2008). A permanent effect in learning abilities of the user is common for those who start using drugs at adolescent stage. Use of drugs causes some areas of brain not to develop properly leading to learning disabilities. Continued use of drugs leads to loss of memory and judgment. Many drug users are forgetful and can hardly concentrate; it can also lead to loss of short- term memory. Drug use may impair memory by slowing down the coordination information and may reduce student's ability to remember information that was learned prior to using drugs. Drug abuse amongst the global youth population has become a serious problem affecting everyone. Addiction leads many people, young people prominent amongst them, into downward spiral of hopelessness that in some cases ends fatal. They range from gluesniffing street children and teenage ecstasy users, to hard core heroin and cocaine addicts (Nacada,2005). Many of our youths ignorantly or knowingly depend on one drug or the other for their daily activities. According to the statistics provided by World Health Organization (WHO), drug including alcohol and tobacco, have caused a lot of road accidents and have claimed more lives than other sicknesses suffered by mankind.

\subsection{Statement of the problem.}

Wukari in Taraba state has experienced rapid growth of population in recent years; the increasing demand for education has led to more schools. Due to rapid development, drug abuse has become common among students in campus and is even affecting their performances in class. Despite the worldwide concern and education about the dangers of drug abuse, most of the students have limited knowledge of how dangerous the habit is (Ngesu,2008).

This study therefore seeks to establish the correlation between poor academic performance and the use of drugs in universities in Wukari.

\subsection{Aim and objectives.}

\section{AIM}

To investigate the effects of drug abuse on students' academic performance.

The objectives of this study are;

To determine whether drug abuse affects students' disciples and interest in learning among students in Wukari 
To determine effects of drug abuse on academic performance among students in Wukari.

\subsection{Hypotheses.}

The hypotheses of the study are:

H0: Drug abuse has no effect on academic performance among students in Wukari.

H1: Drug abuse has effect on academic performance among students in Wukari.

\section{RELATED LITERATURE}

Drug abuse means willful misuse of drugs which often lead to the point of addiction (Muhammad Zaman et al, 2015).

Magidson et al (2016) found that drug use and (alcohol) are strongly associated with violence and sexual activity for both males and females.

Evidence also points to the fact that youth are also prone to drug abuse because of their vulnerability (Mohasoa,2010). Youths become vulnerable because they are in a phase of substantial experimentation, they are unemployed, have no income, and are poor, among other things (Kadalie \& Thomas, 2013; Parry et al., 2012). A study carried out by Oteyo and Kariuki (2009) indicate gross impairment and decline in academic performance as a result of drug use. Drugs reduce number of hours spend studying.

Pluddemann et al, (2010) found that school going youths who used methamphetamine were characterized by delinquent behaviour and engaged in sexual practices more frequently than those who had not used this substance.

Magidson, et al (2016) tests the association between drug use and sexual activity, violence for both males and females in peri-urban areas. In a sample of 822, 1618 year olds, and using logistic regression models, Wechsler (1998) was of the opinion that poor academic performance among students (undergraduates) has several indicators such as students failing in test, being absent in class, dropping out of school and poor grades. Prevalence of drug abuse has caused the concern that the students who use drugs are likely to perform poorly (Oteyo and Kariuki, 2009).

According to Ngesu, Ndiku and Masesi, 2008) students who use drugs have unexplained mood swing, behave negatively, they are argumentative, confused, destructive, anxious over reactive to criticism, act rebellious and doesn't seem happy.

World Health Organization (WHO 2006) stated that the drugs commonly abused include cannabis sativa (marijuana or Indian hemp), cocaine, morphine, opium, tobacco, alcohol etc. The sale and consumption of these drugs has caused a lot of problems in Nigerian society and in international community.

\section{METHODOLOGY}

This research work presents the application and systematic procedures of Chi square analysis in estimating the effects of drug abuse on academic performance among Tertiary students in Wukari.

\subsection{Source of Data}

Questionnaire was used for data collection. The questionnaires were distributed to the student of two tertiary institutions in Wukari, namely Federal University, Wukari and Kwararafa University, Wukari.

Table 1: Data gotten from the questionnaires

\begin{tabular}{|c|c|c|c|c|}
\hline \multicolumn{3}{|l|}{$\overline{K U W}$} & \multicolumn{2}{|l|}{ FUW } \\
\hline & $\begin{array}{l}\text { YE } \\
\mathbf{S}\end{array}$ & NO & YES & NO \\
\hline Forgetfulness & 51 & 28 & 83 & 20 \\
\hline Anxiety & 53 & 26 & 77 & 26 \\
\hline Depression & 53 & 26 & 90 & 13 \\
\hline Self -control & 52 & 27 & 67 & 36 \\
\hline $\begin{array}{l}\text { Learning } \\
\text { ability }\end{array}$ & 20 & 59 & 32 & 71 \\
\hline $\begin{array}{l}\text { Improved } \\
\text { memory }\end{array}$ & 22 & 57 & 33 & 70 \\
\hline $\begin{array}{l}\text { Wild mood } \\
\text { swing }\end{array}$ & 51 & 28 & 41 & 62 \\
\hline Confusion & 47 & 32 & 56 & 47 \\
\hline $\begin{array}{l}\text { Complication } \\
\text { of mental } \\
\text { illness }\end{array}$ & 9 & 70 & 22 & 81 \\
\hline
\end{tabular}


International Journal of Engineering Applied Sciences and Technology, 2020

Vol. 4, Issue 9, ISSN No. 2455-2143, Pages 324-328

Published Online January 2020 in IJEAST (http://www.ijeast.com)

\begin{tabular}{|l|l|l|l|l|}
\hline Hallucinations & 15 & 64 & 44 & 59 \\
\hline
\end{tabular}

3.2 Sampling Techniques: Sampling means selecting a given number of subjects from a defined population as representative of the population. Any statement made about the sample should also be true about the population (Orodho 2002). Gay(1992) recommends that when the target population is small(less than 1000), a minimum sample of $20 \%$ should be adequate. In this research work, the sample size was determined using the Solven's formula

$n=\frac{N}{N\left(e^{2}\right)}$

Where $n=$ Sample size

$\mathrm{N}=$ Total population

$\mathrm{E}=$ Margin of error(5\%or 0.05)

\subsection{Chi - Square Distribution.}

Chi -square distribution is a theoretical or mathematical distribution which has wide applicability in statistical work. Chi - square statistic was discovered by an English Mathematician named Karl Pearson (Pearson 1990). This statistic involves some techniques that permit us to test hypothesis about a given population. Therefore, chi- square test is a hypothesis test that compared the observed distribution of data to an expected distribution of data.

There are many types of chi square but for the purpose of this work, Chi- square Test of Independence was used. Chi- square test of independence is a way of determining whether two categorical variables are associated with one another in the same population. The test statistic is given by:

$\chi_{0}^{2}=\sum_{i=1}^{r} \sum_{j=1}^{c} \frac{\left(O_{i j}-E_{i j}\right)^{2}}{E_{i j}} \sim \chi_{\alpha,(r-1)(c-1)}^{2}$

Where:

$O_{i j}=$ The observed frequencies of $(\mathrm{I}, \mathrm{j})^{\text {th }}$ cell.
$E_{i j}=$ Expected frequency of $(\mathrm{I}, \mathrm{j})^{\text {th }}$ cell.

\subsection{1: Decision Rules}

The decision rule is given as:

Reject the null hypothesis " $H_{O}$ " if $\chi_{o}^{2}>\chi_{\alpha,(r-1)(c-1)}^{2} \quad$ or

Reject the null hypothesis " $H_{O}$ " if $\rho$-value (asymptotic) $<\alpha$, where $\alpha$ is the level of significance.

\section{RESULTS}

The tables below show the analysis of the data based on the earlier stated objectives of the study.

\section{Table 4.1; Kwararafa University(KUW)}

Skipping rows and/or columns filled with zeros. Expected counts are printed below observed counts Chi-Square contributions are printed below expected counts

\begin{tabular}{|l|l|l|l|l|l|l|}
\hline & $\begin{array}{l}\text { Forget } \\
\text { fulnes } \\
\text { s }\end{array}$ & $\begin{array}{l}\text { An } \\
\text { xiet } \\
\mathrm{y}\end{array}$ & $\begin{array}{l}\text { Depr } \\
\text { essio } \\
\mathrm{n}\end{array}$ & $\begin{array}{l}\text { Sel } \\
\mathrm{f} \\
\text { con } \\
\text { trol }\end{array}$ & $\begin{array}{l}\text { Lear } \\
\text { ning } \\
\text { abili } \\
\text { ty }\end{array}$ & $\begin{array}{l}\text { Impr } \\
\text { oved } \\
\text { mem } \\
\text { ory }\end{array}$ \\
\hline 1 & 51 & 53 & 53 & 52 & 20 & 22 \\
& 37.30 & 37. & 37.30 & 37. & 37.3 & 37.3 \\
& 5.032 & 30 & 6.608 & 30 & 0 & 0 \\
& 6.6 & & 5.7 & 8.02 & 6.27 \\
\hline 2 & 28 & 26 & 26 & 27 & 59 & 57 \\
& 41.70 & 41. & 41.70 & 41. & 41.7 & 41.7 \\
& 4.501 & 70 & 5.911 & 70 & 0 & 0 \\
& & 5.9 & & 5.1 & 7.17 & 5.61 \\
\hline $\begin{array}{l}\text { To } \\
\text { tal }\end{array}$ & $\mathbf{7 9}$ & $\mathbf{7 9}$ & $\mathbf{7 9}$ & $\mathbf{7 9}$ & $\mathbf{7 9}$ & $\mathbf{7 9}$ \\
\hline
\end{tabular}


International Journal of Engineering Applied Sciences and Technology, 2020

Vol. 4, Issue 9, ISSN No. 2455-2143, Pages 324-328

Published Online January 2020 in IJEAST (http://www.ijeast.com)

\begin{tabular}{|l|l|l|l|l|l|}
\hline & $\begin{array}{l}\text { Wil } \\
\text { d } \\
\text { Mo } \\
\text { od } \\
\text { swi } \\
\text { ng }\end{array}$ & $\begin{array}{l}\text { Confus } \\
\text { ion }\end{array}$ & $\begin{array}{l}\text { Complic } \\
\text { ation of } \\
\text { mental } \\
\text { illness }\end{array}$ & $\begin{array}{l}\text { Hallucin } \\
\text { ation }\end{array}$ & $\begin{array}{l}\text { Tot } \\
\text { al }\end{array}$ \\
\hline 1 & 51 & 47 & 9 & 15 & 373 \\
& 37. & 37.30 & 37.30 & 37.30 & \\
& 30 & 2.523 & 21.472 & 13.332 & \\
& 5.0 & & & & \\
2 & 32 \\
28 & 32 & 70 & 15 & 417 \\
& $\begin{array}{l}41 . \\
70\end{array}$ & 2.71 .70 & 41.70 & 41.70 & \\
& 4.5 & & 19.206 & 13.332 & \\
\hline $\begin{array}{l}\text { Tot } \\
\text { al }\end{array}$ & $\mathbf{7 9}$ & $\mathbf{7 9}$ & $\mathbf{7 9}$ & $\mathbf{7 9}$ & $\mathbf{7 9 0}$ \\
\hline
\end{tabular}

Table 4.2: Federal University Wukari (FUW)

Skipping rows and/or columns filled with zeros. Expected counts are printed below observed counts Chi-Square contributions are printed below expected counts

\begin{tabular}{|l|l|l|l|l|l|l|}
\hline & $\begin{array}{l}\text { Forgetf } \\
\text { ulness }\end{array}$ & $\begin{array}{l}\text { Anx } \\
\text { iety }\end{array}$ & $\begin{array}{l}\text { Depre } \\
\text { ssion }\end{array}$ & $\begin{array}{l}\text { Sel } \\
\text { f } \\
\text { con } \\
\text { trol }\end{array}$ & $\begin{array}{l}\text { Lear } \\
\text { ning } \\
\text { abili } \\
\text { ty }\end{array}$ & $\begin{array}{l}\text { Impr } \\
\text { oved } \\
\text { mem } \\
\text { ory }\end{array}$ \\
\cline { 2 - 7 } & 83 & 77 & 90 & 67 & 32 & 33 \\
& 54.50 & 54.5 & 54.50 & 54. & 54.5 & 54.5 \\
& 14.904 & 0 & 23.12 & 50 & 0 & 0 \\
& & 9.28 & 4 & 2.8 & 9.28 & 8.48 \\
\hline 2 & 20 & 26 & 13 & 36 & 71 & 70 \\
& 48.50 & 48.5 & 48.50 & 48. & 48.5 & 48.5 \\
& 16.747 & 0 & 25.98 & 50 & 0 & 0 \\
& & 10.4 & 5 & 3.2 & 10.4 & 9.53 \\
\hline To & $\mathbf{1 0 3}$ & $\mathbf{1 0 3}$ & $\mathbf{1 0 3}$ & $\mathbf{1 0 3}$ & $\mathbf{1 0 3}$ & $\mathbf{1 0 3}$ \\
tal & & & & & & \\
\hline
\end{tabular}

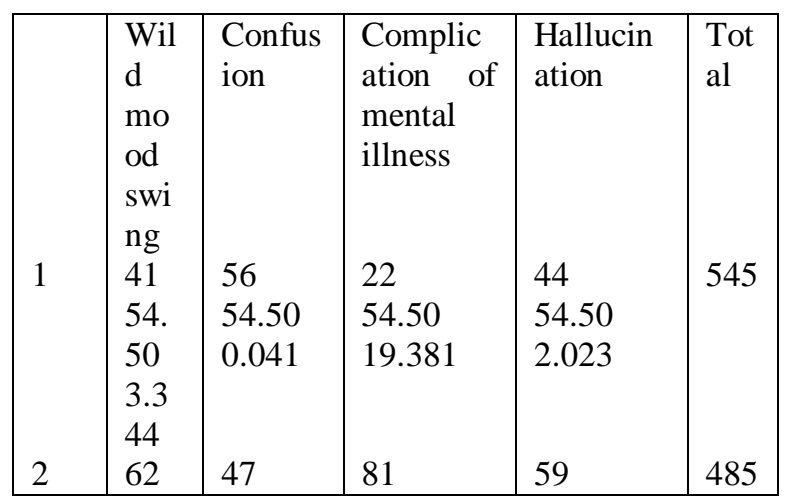

\begin{tabular}{|l|l|l|l|l|l|} 
& $\begin{array}{l}48 . \\
50\end{array}$ & 48.50 & 48.50 & 48.50 & \\
3.7 & & 21.778 & 2.273 & \\
58 & & & & \\
\hline $\begin{array}{l}\text { Tot } \\
\text { al }\end{array}$ & $\mathbf{1 0 3}$ & $\mathbf{1 0 3}$ & $\mathbf{1 0 3}$ & $\mathbf{1 0 3}$ & $\begin{array}{l}\mathbf{1 0 3} \\
\mathbf{0 3}\end{array}$ \\
\hline
\end{tabular}

Chi-Sq $=196.960, \mathrm{DF}=9, \mathrm{P}-$ Value $=0.000$

The table above presents the observed and expected counts/frequencies for the data. The result produced a chi-square value of 196.960 and p-value of 0.000 . Since p-value (0.000) is less than $\alpha$-value $(0.05)$ we reject $H_{0}$ and hence conclude that drug abuse affects academic performance among students in Wukari

\section{DISCUSSION}

From the results of this research, it is discovered that drug abuse affects academic performance among students in Wukari. This is because Chi-square value calculated in table 1 , which is 152.884 is greater that the p-value of 0.000 . Also, in table 2, the calculated chisquare is 196.960 is also greater than the p-value which is 0.000 . Based on these, the null hypothesis was rejected. rather the alternative was accepted.

\section{CONCLUSION}

From the findings of the study, it can be concluded that drug abuse has effect on students' academic performance. This leads to poor academic performance, indiscipline, mental imbalance etc. among students.

\section{REFERENCES}

1. Lewinsohn, D.A.E et al (2007): Immune dominant tuberculosis CD8 antigens preferentially restricted by HLA-B. PloSPathog, 3:1240-1249.

2. Magidson, Jessica F. et al, (2016): Psychosocial correlates of alcohol and other substance use among low-income adolescents in peri-urban Johannesburg, South Africa: A focus on gender differences J Health Psychology, March

3. Manbe, D.A. (2008): Crime and drug abuse among Nigerian youths: A critical examination in World Health Organisation (WHO), expert committee on drug dependence. $28^{\text {th }}$ Report (unpublished).

4. Melgosa, J. (2009): To adolescent and parents: Madrid Spain.

5. Mohasoa, I.P. (2010): Substance abuse among male adolescents. Unpublished MA dissertation. Pretoria: University of South Africa. 
6. Morojele and L Ramsoomar, (2016): Addressing adolescent alcohol use in South Africa, S Afr Med J 2016;106(6):551-553.

7. Ngesu, L.M. (2008): Drug dependence and abuse in Kenyan secondary schools: strategies for intervention. Educational and Review, 3(10):304308.

8. Wechsler, H. et al, (1998): Changes in binge drinking and related problems among American College Students between 1993 and 1997; Results of the Harvard School of Public Health College Alcohol Survey. Journal of American College Health, 47(2):57-68.

9. World Health Organisation (2006): Joint United Nations program on HIV/AIDS, United Nations educational, scientific and cultural organization, United Nations children fund. Geneva, Switzerland.

10. Zaman Ammad et al, (2015): Drug abuse among Students, Pakistan Journal of Pharmaceutical Reseach, Vol01, Issue 01 Pp 41-47 